\title{
迷走神経刺激装置植え込み術に必要な頝部迷走神経と内頝静脈，総䅡動脈と の解剖学的位置関係について
}

高見澤 幸子，森野 道晴

東京都立神経病院脳神経外科・てんかん総合治療センター

\section{Knowledge of Anatomical Relationships of the Vagus Nerve with Inter- nal Jugular Vein and Common Carotid Artery in the Neck Necessary for Vagus Nerve Stimulation（VNS）Surgery}

\author{
Sachiko Takamizawa, M.D., and Michiharu Morino, M.D. \\ Department of Neurosurgery and Epilepsy Center, Tokyo Metropolitan Hospital
}

A precise understanding of the anatomy is essential to perform vagus nerve stimulation (VNS) therapy for refractory epilepsy. We evaluated the anatomical relationships of the cervical vagus nerve with the carotid artery and jugular vein on the basis of findings during VNS surgery.

We investigated the anatomical relationships among the vagus nerve (VN), common carotid artery (CCA), and internal jugular vein (IJV) in 73 patients who underwent VNS surgery at our hospital from December 2010 to January 2015, classified the position of the VN into 5 categories, and studied the frequency of each category.

The position of the VN was medial to the IJV and ventral to the CCA (type 1) in 8 patients (10.9\%), medial to the IJV and lateral to the CCA (type 2) in 4 (5.5\%), dorsomedial to the IJV and ventral to the CCA (type 3 ) in $51(70 \%)$, dorsomedial to the IJV and lateral to the CCA (type 4) in $7(9.5 \%)$, and dorsal to the CCA (type 5) in $3(4.1 \%)$.

This report is the first to propose a classification of the anatomical relationships of the VN with the CCA and IJV based on intraoperative findings. According to this classification, the difficulty of VNS surgery increases with advances of the type. Type 3 was the most frequent, and types 2 and 5 were rare.

Understanding the variation in the position of the cervical vagus nerve is considered to contribute to safer surgical manipulations in VNS surgery.

(Received April 3, 2015 ; accepted May 15, 2015)

Key words : vagus nerve stimulation (VNS) surgery, vagus nerve (VN), internal jugular vein (IJV), common carotid artery (CCA)

Jpn J Neurosurg（Tokyo） $24: 705^{-711, ~} 2015$

\section{はじめに}

迷走神経刺激療法 (vagus nerve stimulation：VNS）は, 1997 年に米国食品医薬品局 (FDA) の承認を受けた難治 性てんかんに対する緩和治療である。本邦でも 2010 年
7 月に保険適用されて以来，てんかん発作の緩和を目的

とした低侵襲治療として普及している。

VNS は, 迷走神経を電気刺激し, てんかん発作を抑制 する治療である。実際には，左䅡部の迷走神経にらせん 状の電極装置を巻きつけて, その電極に連結している

連絡先：高見澤幸子, $\bar{\top} 183-0042$ 府中市武蔵台 2-6-1 東京都立神経病院脳神経外科

Address reprint requests to: Sachiko Takamizawa, M.D., Department of Neurosurgery, Tokyo Metropolitan Hospital, 2-6-1 Musashidai, Fuchu-shi, Tokyo 183-0042, Japan 
リード線と電気刺激発生装置（ジェネレーター）を左胸 部〜腋窩部の皮下に埋め込んで使用する. VNS は患者の 年齢やてんかん分類および発作型による制限を受けず, 薬剂抵抗性の難治性てんかんに広く適応がある有効な治 療法である。迷走神経の電気刺激により, 脳波変化がも たらされることは古くから示されてきたが, 論理的背景 や作用機序はいまだ明らかではない。また, 注意すべき ことは, 発作焦点切除が可能な症例には基本的に開頭術 を第一選択とし，VNS はあくまでも開頭術が適応となら ない症例や, 多焦点例で焦点切除後に遺残発作が残存し た症例などの発作緩和治療として行うべきことである. 適応を選ばずに，やみくもにVNS を施行することは， 抑制されるべきてんかん発作の残存をもたらしかねな い.われわれの施設では，多焦点性のてんかんで，脳梁 離断術後に部分てんかんが残存する例や, 脳炎後遺症に みられるような両側側頭葉てんかんをVNS の適応とし ている。

VNS は手術手技が比較的容易であり, 脳神経外科医の 習得すべき手術法の一つである。しかし，迷走神経は広 く重要藏器を支配しており, 特に頝部迷走神経は心臟枝 を分岐しているため，迷走神経やその枝の損傷は，重篤 な合併症をもたらしかねない。また迷走神経は周囲に総 頚動脈や内頝静脈が存在し, 大血管に手術操作が及ぶリ スクを伴う。狭い術野で安全に本手術を行うには, 術者 に手術に関する解剖学的知識の習熟が求められるのはい うまでもないが，いくら解剖を勉強して手術に臨んでも 迷走神経を同定するのに難渋する場合がある。われわれ は迷走神経を術中に適切に同定するのが困難であった症 例に着目して, 迷走神経と総䅡動脈および内䅡静脈の解 剖学的位置関係について研究したところ, いくつかのバ リエーションが存在することがわかり, 手術難易度を考 慮して 5 つのタイプに分類した。

本稿では迷走神経刺激術の手術法を述べながら, 予め 知っていれば安全かつ正確な手術を行うことに有用であ る, 迷走神経と総頝動脈および内頝静脈の解剖学的位置 関係の新しい分類について述べる.

\section{VNS の手術手技}

迷走神経と総頝動脈および内頝静脈の解剖学的位置関 係の新しい分類を述べる前に, 当施設の VNS の手術法 について述べる ${ }^{3)}$. 頝動脈内膜剝離術 (carotid endarterectomy：CEA）の手術経験がある脳神経外科医であれば, VNS の術式は決して難しいものではないが, CEA を経 験していない初心者でも安全に手術が行えるようにする
ためのコツがある。

まず体位が非常に重要で，腕を閉じた仰臥位とし，上 体はやや挙上して䅡部は伸展位をとることにより, 頝部 の皮膚に弛みのない術野を確保する。頭部は馬蹄型頭部 固定器を用いて，正中位に固定する．右側へ頚部を回旋 すると, 左側胸鎖乳突筋が引つ張られて, 強い緊張をも ち, 術野に覆いかぶさるので, 迷走神経に到達するのが 困難になる。また，CEA よりも低位レベルでの手術のた め，頝部を伸展位にすれば，正中位であっても下顎が術 野の妨げになることはない.

術者は患者の左側に立ち，皮膚切開時より顕微鏡下に 手術操作を行う.顼部の皮膚切開は輪状軟骨のレベルで, 正中から左側へ皮膚割線に沿った $30 \mathrm{~mm}$ 長の切開線を もうける. 皮膚切開のレベルは, 適切な電極留置位置を 意識して行う。頝部迷走神経から心㵴枝が分岐する部位 は頝椎第 3,4 レベルとされているが, 頝部迷走神経を なるべく低位まで観察し，心臓枝のないことを確認して から電極留置を行うことが重要である.

皮膚切開後, 広頝筋を皮膚切開線と同ラインで切離し, 胸鎖乳突筋前縁を露出し, これを外側に牽引する. 次に, 術野内側に肩甲舌骨筋と胸骨舌骨筋が観察されるので, これら 2 筋の間を十分に剝離し, 両者を内側に牽引する と, 頚動脈三角を適切に露出することができる.内䅡静 脈（internal jugular vein：IJV）の内㑯面に沿つて結合織 の剝離を行い, これを外側に牽引すると, 深部に総頝動 脈 (common carotid artery：CCA) が確認される。この時 に動静脈と迷走神経の解剖学的位置関係にバリエーショ ンを認めるため，この手術過程での迷走神経の正確な同 定が手術を円滑に進める大きなポイントとなる。迷走神 経への電極留置を行い, 最後にリードとジェネレーター を接続し, ジェネレーターを皮下ポケットに埋め込む. 埋め込む前および埋め込み後に，システム診断と試験刺 激を行い, 誤作動や心電図異常のないことを確認して, 手術を終了する.

\section{方 法}

VNS を円滑に行うために最も重要な点は, 迷走神経の 迅速で正確な同定である。一般に迷走神経は頝動脈鞘内 で，IJV と CCA の間に位置するとされているが，個体差 により簡単に迷走神経が確認できない場合がある。当院 では 2010 年 12 月より 104 例に VNS を施行したが，術 中に迷走神経の同定に難渋した症例がいくつか存在した ことで，決して迷走神経がそれを取り巻くIJV および CCA と一定の解剖学的位置関係をとつているわけでは 
A

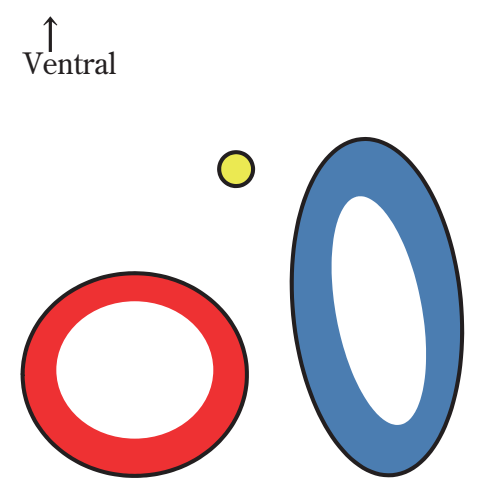

B

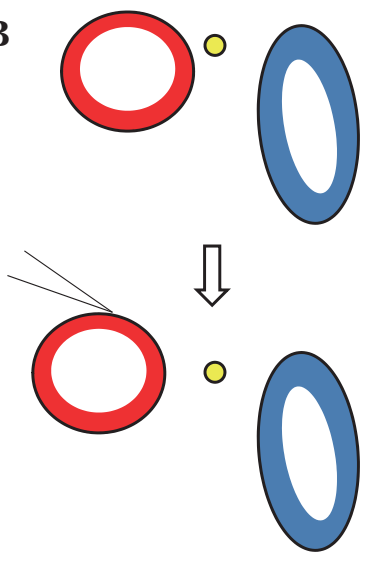

C
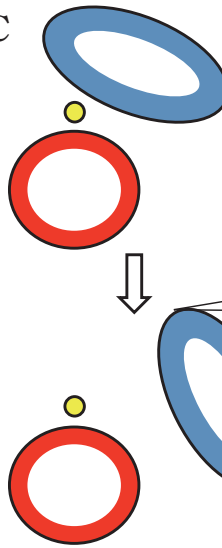
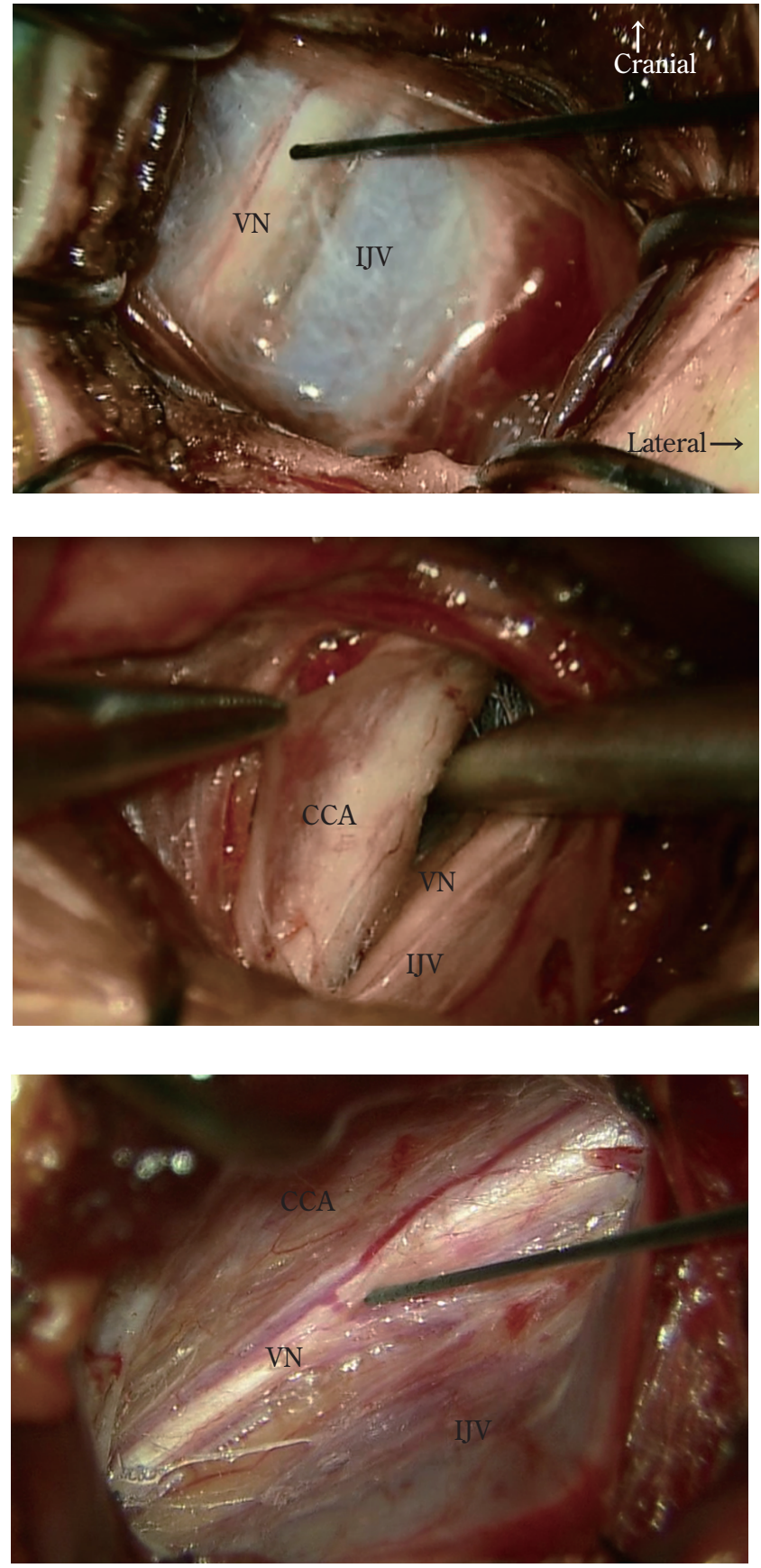

Fig. 1 Variation in the anatomical position of the vagus nerve

The position of the left vagus nerve (VN) relative to the left common carotid artery (CCA) and left internal jugular vein (IJV) seen from below are shown as schemes and intraoperative photographs. Yellow circle: VN, blue circle: IJV, red circle: CCA

A : Type 1. Medial to the IJV and ventral to CCA.

B : Type 2. Medial to the IJV and lateral to the CCA.

C : Type 3. Dorsomedial to the IJV and ventral to the CCA.

D : Type 4. Dorsomedial to the IJV and lateral to the CCA.

E : Type 5. Dorsal to the CCA. 

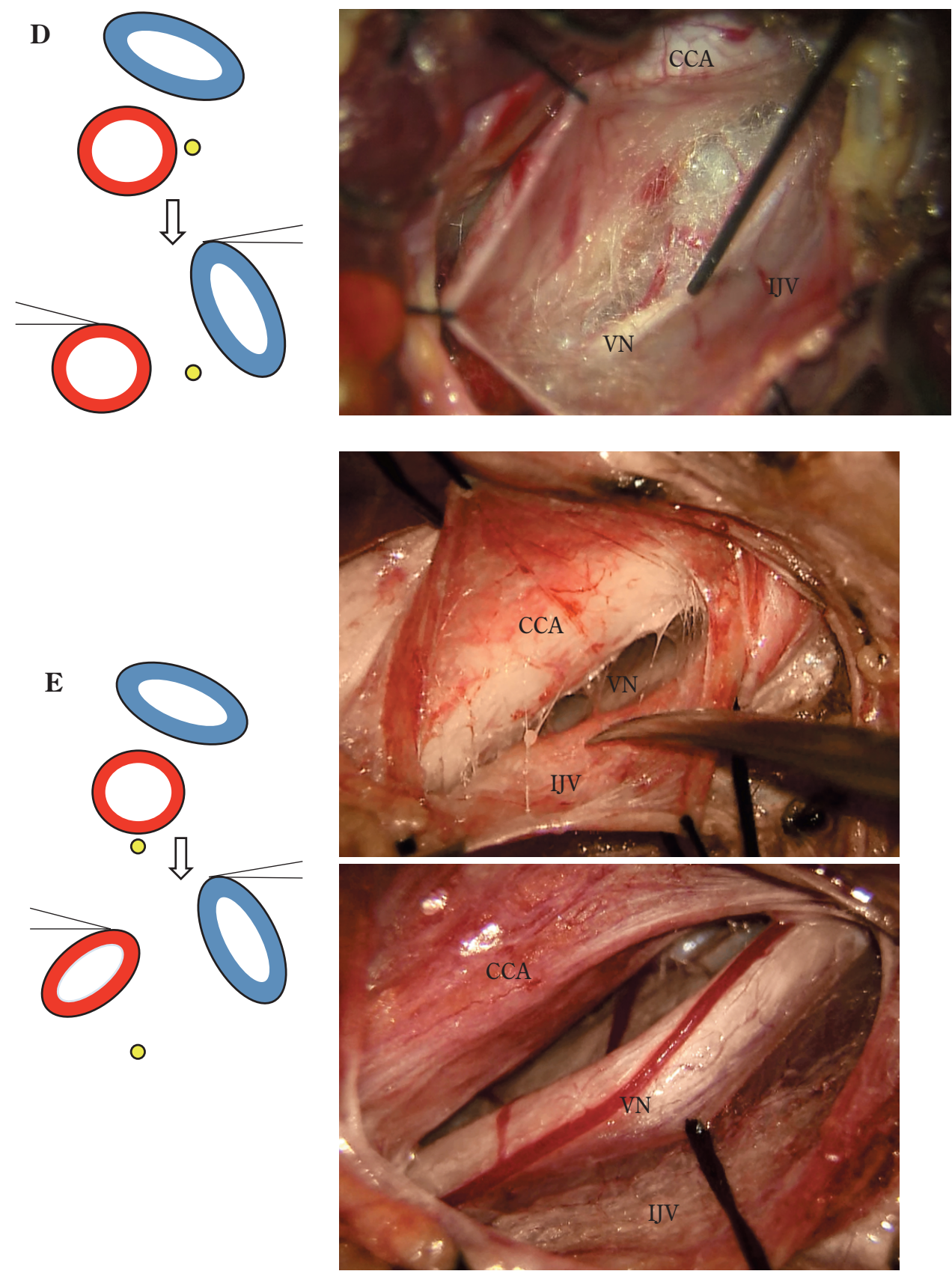

Fig. 1 (cont'd)

ないと考えた。当院において 2010 年 12 月〜2015 年 1 月の期間に, 主術者あるいは主術者の指導下に VNS を 行った 73 例を対象とし, 手術ビデオを再検討すること により, 迷走神経と IJV, CCA の解剖学的位置からタイプ を分類し，さらにそれぞれの夕イプが手術難易度にぞの ような影響があったのかを後方視的に考察した。迷走神 経の位置を以下の 5 つの夕イプに分類した。

Type 1: IJV 内側で CCA 腹側（Fig. 1A）

Type 2: IJV 内側で CCA 外側（Fig. 1B）

Type 3：IJV 内背側で CCA 腹側（Fig. 1C)
Type 4：IJV 内背側で CCA 外側（Fig. 1D）

Type 5: CCA 背側（Fig. 1E)

\section{結 果}

VNS を初回施行された 73 例の内訳は，男 39 例，女 34 例であった。平均年齢は 29 歳（1６7 歳）で， 16 歳 未満の小児は 12 例含まれた。平均身長は $153 \mathrm{~cm}$ （80〜 $189 \mathrm{~cm})$, 平均体重は $54 \mathrm{~kg}(11 \sim 97 \mathrm{~kg})$, 平均 BMI は 22 であった。 
VNS の手術所見から迷走神経と IJV，および CCA の解 剖学的位置関係とその手術難易度を考慮した分類は, わ れわれが渉猟したかぎり初めての報告である。

内訳は, Type 1:8 例 (10.9\%), Type 2: 4 例 (5.5\%), Type 3:51 例 $(70 \%)$, Type 4:7 例 (9.5\%), Type 5:3 例 $(4.1 \%)$ であった。そのうち 16 歳未満の小児例の内 訳は, Type 1: 0 例 (0\%), Type 2: 0 例 $(0 \%)$, Type 3： 9 例 $(75 \%)$, Type 4:2 例 (17\%), Type 5:1 例 (8\%) であった。

タイプ別の平均年齢は Type $1: 34$ 歳, Type $2: 25$ 歳, Type $3: 28$ 歳, Type $4: 29$ 歳, Type $5: 25$ 歳. タイプ別 平均 BMI は Type $1: 22 \mathrm{~kg} / \mathrm{m}^{2}$, Type $2: 21 \mathrm{~kg} / \mathrm{m}^{2}$, Type $3: 21 \mathrm{~kg} / \mathrm{m}^{2}$, Type $4: 21 \mathrm{~kg} / \mathrm{m}^{2}$, Type $5: 23 \mathrm{~kg} / \mathrm{m}^{2}$ で あった。

タイプ別の手術時間の平均は, Type 1:96 分, Type $2: 91$ 分, Type $3: 97$ 分, Type $4: 104$ 分, Type $5: 128$ 分 であった. Type $1 \cdot 2 \cdot 3$ と Type $4 \cdot 5$ の間に有意差は認 めなかった $(\mathrm{p}=0.06)$.

\section{考 察}

VNS の手術手技は, 経験がある脳神経外科医にとって は難しいものではないが, 経験の浅い術者や VNS 初心 者にとっては迷走神経の安全かつ正確な同定は最も難し いステップとなり得る。一般に頝部迷走神経は IJV と CCA の間を走行するとされており, VNS 手術の際には $\mathrm{IJV}$ を外側に剶離した後, 直下にみえる CCA と IJV の間 の結合織を丁寧に剝離することで迷走神経を同定できる ことが多い.しかし実際には，そもそも IJV と CCA の 2 血管の位置関係にバリエーションがあり, さらにこれ らの間に迷走神経が存在しないこともある。 バリエー ションの違いは術野の浅さ深さに影響したり, 手術操作 の段階を増やしたりする。

各夕イプの解剖学的特徴と, 術野の深さや操作の煩雑 さの違いを紹介する。なお手術は全例, 主術者あるいは その指導下に施行しているため, 手術体位, 顕微鏡の角 度等は一定しており, 術者の相違による解剖学的位置関 係の変化はほとんどなかった。

Type 1 は迷走神経と IJV が同じ深さを走行している ため, 比較的容易に迷走神経を同定できる夕イプである. IJV を外側に牽引しなくとも迷走神経に対する手術操作 をすることができるため術野が浅くなり, 手術操作はや さしい. また, CCA はより深部に存在しているため, 術 野で観察されることがなく, 血管損傷のリスクが少ない.

Type 2 は Type 1 と同様に迷走神経と IJV が同じ深さ
を走行するが, CCA も同じ深さに存在する，そのため迷 走神経への操作にあたり, IJV の牽引は必要ないが, 弾 性の強い CCA は内側に牽引する必要があるので, やゃ 操作が複雑となる. Type 1 と比較して術野の深さは変わ らないが, 操作がやや複雑になるので難易度が上がる.

Type 3 は最もよく認められる夕イプである. 迷走神経 の腹側に IJV が存在するため, IJV を外側に牽引する必 要がある. CCA は迷走神経より深部に存在するので, 牽 引の必要はない. Type 2 と比較し, 操作回数は同じだが, 術野が深くなるので, 難易度は上がる.

Type 4 は Type 3 と同様に迷走神経の腹側に IJV が存 在するため, IJV を外側に牽引する必要がある。ささらに CCA は迷走神経の外側に存在するため, 弾性の強い CCA も内側に牽引する必要がある. Type 3 と違い, 動静 脈の牽引操作を必要とし, 術野も深くなるので難易度は 高くなる。

Type 5 は, Type 3 や Type 4 と同様に迷走神経の腹側 に IJV が存在するため, IJV を外側に牽引する必要があ る.さらに CCA も迷走神経の腹側に存在するため, CCA を十分内側に牽引する必要がある. 動静脈の強い牽引操 作が必要で, 術野が最も深い夕イプであり, 最も難易度 が高い.

タイプ別の分類では, Type 3 が最も多く, 全体の $70 \%$ を占めた. また, Type 2 と Type 5 は $5 \%$ 前後と頻度が低 かった. 今回の結果から，一般的と考えられていた Type 3 は実際には $2 / 3$ 程度の頻度であることがわかった。

Type 3 のみを念頭に置いて手術を行っていては迷走神 経の同定に戸惑うことも多くなる．基本的には Type 3 の解剖構造を念頭に置き, Type 3 の位置に迷走神経がな い場合には，より深層に迷走神経がないかどうか（Type 4，5），あるいはより浅層に迷走神経が走行しているこ とを見逃していないかどうか（Type 1，2）をチェックす ることが大切である.

IJV と CCA および迷走神経の解剖学的位置関係に着 目したこの分類はタイプが 1 から 5 へ進むにつれて, 迷走神経の走行が深部になり, 血管の牽引操作が増え, 手術手技は困難になる傾向がある。しかしわれわれの分 類で述べた難易度は, 術者の主観的な要素を含んでいる 面がある. 実際，迷走神経の同定がやさしいと思われた Type $1 \cdot 2 \cdot 3$ と, 同定が難しいと思われた Type $4 \cdot 5$ の 手術時間を比較したところ, 明らかな有意差は認められ なかった. しかし, Type $4 \cdot 5$ では, Type $1 \cdot 2 \cdot 3$ より も長時間となる傾向があり, 難易度を反映している可能 性が示唆された。

このような解剖学的位置関係のバリエーションは, 個 
人の年齢や体格に左右されていることが予想されたが, 今回の研究では，関係性はみられなかった。これらのバ リエーションは発生段階ですでに形成されている可能性 が高い.

迷走神経と頝動静脈のバリエーションについて考える とき, これらの発生や一般的な解剖構造を知っておく必 要がある.

胎生 4 5 週，心臓から連続する腹側・背側大動脈弓 の間に, 左右 6 対の大動脈弓が形成され, 胎生 6 週まで に第 $1 \cdot 2 \cdot 5$ 大動脈弓は消失する。この時すでに頝部迷 走神経は, 大動脈弓の脇を走行した後, 将来の大動脈弓 である第 6 大動脈弓で折り返して反回神経を形成する.

頝部の臓器発生段階で迷走神経および䅡部血管がどの ように関わり, 発生していくのかはいまだ不明な点も多 い.しかし, 形成後のバリエーションについては調査さ れており, 頝動脈エコーにおける IJV と CCA の位置関 係や表在エコーにおける甲状腺と頝部迷走神経および頝 動静脈の位置関係については, 種々の報告がある。特に 頝静脈からの中心静脈カテーテル挿入において, IJV と $\mathrm{CCA}$ が腹背側の同一ライン上に位置して重なっている と，CCA を誤って穿刺してしまう危険性がある。そのた め, これら動静脈が重なって存在する頻度や重なりの程 度, 体位・年齢による重なり方の違いについてしばしば 検討されてきた。

Troianos $ら^{7)}$ はカテーテル挿入を目的とした 1,009人 の右䅡動脈エコー所見から，CCA に対して IJV が重なら ない場合, つまりわれわれの提唱する Type 2 に相当す るものは $6.4 \%$ みで, 多くの場合は程度の差こそあれ, 両者が腹背側に重なる（われわれの分類の Type 1,3,4,5） と報告した。同じく成人の䅡動脈エコー 219 例におい て, CCA に対する IJV の位置関係を細かく分類した Shoja ら ${ }^{5)}$ の報告によると, 重なる夕イプの中でも, IJV が CCA に完全に覆いかぶさる夕イプは少なく(前方型： 右 $1.4 \%$, 左 $1.8 \%)$, 多くは部分的に重なる夕イプであっ た（前外側型：右 $84 \%$, 左 $91.8 \%$ ).

さらに Turba $ら^{9)}$ の 188 人の左䅡動脈エコーの結果に よると, 部分的に重なる夕イプといっても重なりの程度 に差があり, CCA に対して IJV の大部分が重なる夕イプ は少なく（CCA に対して IJV がななめ 60 度外側方向に 存在：9\%), 多くは一部分のみが重なる夕イプ（CCAに 対して IJV がななめ 30 度外側方向に存在する： 75\%)で あるという。

今回のわれわれの分類では CCA に対する IJV の位置 は, Type 1，3，4，5 のように IJV が CCA の腹側に重な るタイプが $94.5 \%$ と大半を占め, Type 2 のように IJV
が CCA に重ならず CCA の外側に存在するタイプは, 5.5\%と少なかった。われわれの分類は手術所見を基にし ているため, 頝動脈エコー所見と完全に一致するもので はないが，過去の報告と矛盾しない結果となった。体位 に関しては䅡部を対側に回旋すると䅡動静脈が重なりや すくなる ${ }^{6)}$. また年齢別にみると 5 歳以下の小児では頝 動静脈が重ならない症例が $66 \%$ を占めるのに対し ${ }^{2)}, 60$ 歳以上では動脈硬化により頝動静脈の重なりの程度が強 くなるとされる ${ }^{7)}$. 当院での VNS 症例の平均年齢は 29 歳で, 幼小児や高齢者層が少ないことから，われわれの 研究では, 年齢による迷走神経走行バリエーションに有 意差がみられなかったと考えられた。

表在エコーを基に頝部迷走神経の走行を CCA との位 置関係でまとめた Ha $~^{1)}$ の報告では迷走神経が CCA の外側にあるもの, 腹側にあるもの, 内側にあるもの, 背側にあるものがおのおの $76.9 \%, 21.1 \%, 1.6 \%, 0.3 \%$ であった。

頝部迷走神経の上下方向の連続的な走行バリエーショ ンについては, Park ら ${ }^{4)}$ が 163 例, 326 個の迷走神経の表 在エコー所見を報告している。通常, 迷走神経は CCA の 外側を頭側から尾側に向けてルートを変更せずに走行す るが, $5.5 \%$ で迷走神経がルートを変更する症例が存在す

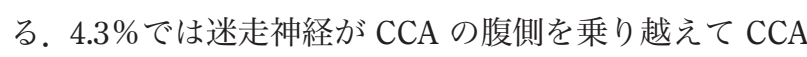
の内側へとルートを変更しており，1.2\%では CCA の背 側を走行して CCA の内側へとルートを変更していると され，後者の夕イプがわれわれの分類の Type 5 に相当 すると思われる。

迷走神経が CCA の腹側を乗り越えるバリエーション については, Tubbs $ら^{8)}$ が報告した剖検 1 例と類似して おり, 発生段階に打ける, 甲状腺と迷走神経間のもつれ に起因していると考察している.

今回のわれわれの分類では, CCA に対する迷走神経の 位置関係は, Type 1〜4のような腹側, 外側型が大半を占 め $(95.9 \%)$, Type 5 のような背側型は少なく $(4.1 \%)$, やはり画像所見を基にした過去の報告と矛盾しない内訳 となった。

IJV と CCA および頝部迷走神経の位置関係のバリ エーションは, 性別や体格による明らかな有意差は得ら れておらず, 主に発生段階での臟器周囲結合織の発達程 度に左右されると考えられる。また年齢による差異もあ るが, VNS 患者ではその年龄分布ゆえ，大きな影響はな い.そのため VNS 術前に患者の情報から頚部迷走神経 の走行パターンを予測することは難しい. 一方で過去の 報告と本研究の比較から, 画像検査と実際の手術所見の 解剖学的位置関係は比較的一致すると考えられた。 


\section{結 語}

今回われわれは，VNS 手術の際に CCA と IJV および 頚部迷走神経の解剖学的位置関係のバリエーションにつ いて手術操作の難易度を考慮した分類を行った．IJV と CCA および頝部迷走神経の走行は非常に個人差が多い. VNS 手術において, より安全で正確な手術を行うために は, 手術過程の中で適切に迷走神経を確認する必要があ る.そのためには, 迷走神経と IJV および CCA の解剖学 的位置関係のバリエーションとその頻度を念頭に置い て，手術に臨むことが重要である。

\section{研究費交付および謝辞など}

日本脳神経外科学会への COI の自己申告を完了して います. 本研究において報告する COI はありません. 本 報告の要旨は第 124 回日本脳神経外科学会関東支部学 術集会にて報告しました。

\section{文 献}

1) Ha EJ, Baek JH, Lee JH, Kim JK, Shong YK : Clinical significance of vagus nerve variation in radiofrequency ablation of thyroid nodules. Eur Radiol 21:2151-2157, 2011.

2）茅島顕治，今井敬子，宗前玲子：超音波画像による小児 の総頸動脈と内頸静脈の重なりの検討。麻酔 62：161-
167, 2013.

3）森野道晴: 写真と動画で学ぶてんかんの手術．難治性て んかんに対する手術の極意を伝授. 東京, メジカルビュー 社, 2013.

4) Park JK, Jeong SY, Lee JH, Lim GC, Chang JW: Variations in the course of the cervical vagus nerve on thyroid ultrasonography. AJNR Am J Neuroradiol 32:11781181, 2011.

5) Shoja MM, Ardalan MR, Tubbs RS, Loukas M, Vahedinia S, Jabbary R, Jalilvand M, Shakeri A: The relationship between the internal jugular vein and common carotid artery in the carotid sheath: the effects of age, gender and side. Ann Anat 190:339-343, 2008.

6) Sulek CA, Gravenstein N, Blackshear RH, Weiss L: Head rotation during internal jugular vein cannulation and the risk of carotid artery puncture. Anesth Analg 82:125128,1996

7) Troianos CA, Kuwik RJ, Pasqual JR, Lim AJ, Odasso DP: Internal jugular vein and carotid artery anatomic relation as determined by ultrasonography. Anesthesiology 85: 43-48, 1996.

8) Tubbs RS, Loukas M, Shoja MM, Blevins D, Humphrey R, Chua GD, Kelly DR, Oakes WJ: An unreported variation of the cervical vagus nerve: anatomical and histological observations. Folia Morphol (Warsz) 66: 155-157, 2007.

9) Turba UC, Uflacker R, Hannegan C, Selby JB: Anatomic relationship of the internal jugular vein and the common carotid artery applied to percutaneous transjugular procedures. Cardiovasc Intervent Radiol 28:303-306, 2005.

\section{迷走神経刺激装置植え込み術に必要な頚部迷走神経と}

内頚静脈, 総頚動脈との解剖学的位置関係について

高見澤幸子＼cjkstart森野 道晴

難治性てんかんに対する迷走神経刺激療法は, 比較的手術手技が容易であるが, 迷走神経の正確で 迅速な同定が重要である. 迷走神経とその周囲の総頚動脈 (CCA) および内頚静脈 (IJV) の解剖学的 位置関係にはバリエーションが多く, 症例によっては迷走神経の同定に難渋することがある. われわ れは，頚部迷走神経の走行を CCA，IJV との位置関係から 5 つのタイプに分類した.

Type 1：IJV 内側で CCA 腹側, Type 2：IJV 内側で CCA 外側, Type 3： IJV 内背側で CCA 腹側, Type 4: IJV 内背側で CCA 外側, Type 5: CCA 背側.

最も頻度が高いのは Type 3 である. Type 1 から 5 になるにしたがい, 手術手技が煩雑になり，難 易度も高くなる.このような解剖学的バリエーションを念頭に置いて VNS 手術に臨むことは, 初心 者でも安全で正確な手術を行ううえで効果的である. 


\section{Editorial Comment}

\section{迷走神経刺激}

東京女子医科大学脳神経外科 平 孝臣

迷走神経を電気刺激するとてんかん発作が低減す るという認識は, 脳波の歴史と同程度の古い歴史が あり, 刺激により脳波が非同期化するという知見か ら研究が始まった。 ヒトへの応用は 1990 年代前半 から行われ，その効果は確立されている。一方で, 米国などでは本治療がやや乱用されている感もあ り, うつ病や痛みなどへの応用もされ, 頚部や耳介 部の迷走神経を経皮的に刺激するという試みもなさ れている。本邦では適正使用のため術者の資格が限 定されており，良好な quality control がなされてい ることが非常に評価できる点である。私自身は治験 の段階から本治療に関与して治療後 20 年を経過し
た例を経験しているが，この数年は一度も発作をき たしていない.

本論文は，頝部迷走神経と頝動脈，頝静脈との関 係を多くの経験から具体的に記載したもので，より 正確で低侵襲な手術のために非常に有用な情報が記 載されている。また, 頚動脈血栓内膜剝離術におい ても有用な知見と考えられる. 普段何気なく行って いる手技の中で，詳しく記録して記載するというこ との重要性を示唆する優れた論文であると考える. 今後さらに迷走神経刺激の効果の機序が解明されて いくことを期待する. 